\title{
Novas espécies de Manihot (Euphorbiaceae) do Brasil Central
}

New species of Manihot (Euphorbiaceae) from Central Brazil

\author{
Moises Mendoza ${ }^{1,3}$, Marcelo F. Simon ${ }^{2}$, Thalyssa K.M. Arquelão ${ }^{2}$ \& Taciana B. Cavalcanti ${ }^{2}$
}

\begin{abstract}
Resumo
Estudos em herbários e intenso trabalho de campo voltados para abordagens taxonômicas atuais e filogenia do gênero Manihot no cerrado brasileiro possibilitaram a descoberta de cinco novas espécies ocorrentes em áreas de cerrado de Brazlândia (Distrito Federal), Padre Bernardo, Água Fria, São João D’Aliança e Niquelândia (Goiás). Manihot brasiliana, M. congesta, M. incisa, M. pinatiloba e M. porphyrantha são descritas e ilustradas. Características morfológicas dos novos táxones, suas relações com espécies mais estreitamente relacionadas, como também comentários sobre aspectos ecológicos e de distribuição natural para cada espécie, são fornecidos.
\end{abstract}

Palavras-chave: Cerrado, endemismo, taxonomia, terras altas.

\begin{abstract}
Studies in herbaria and intensive field work focused on modern taxonomic approaches and phylogeny of the genus Manihot in the Brazilian cerrado enabled the discovery of five new species occurring in cerrado areas from Brazlândia (Distrito Federal) and Padre Bernardo, Água Fria de Goiás, São João D’Aliança and Niquelândia (Goiás). Manihot brasiliana, M. congesta, M. incisa, M. pinatiloba and M. porphyrantha are here described and illustrated. Morphological characteristics of these new taxa, relationships with closely related species, as well as comments on ecological aspects and natural distribution for each species, are provided.
\end{abstract}

Key words: Cerrado, endemism, taxonomy, highlands.

\section{Introdução}

O gênero Manihot Mill. é um dos mais importantes dentro da família Euphorbiaceae, particularmente pela relevância da cultura da "mandioca". O último tratamento taxonômico realizado para o gênero registrou 98 espécies para os Neotrópicos (Rogers \& Appan 1973). Cordeiro et al. (2015) referem 76 espécies de Manihot para o Brasil, encontradas principalmente em habitats secos, rochosos e em campos do cerrado e florestas secas.

O centro primário de diversidade do gênero está localizado no Cerrado do Brasil Central (Rogers \& Appan 1973), onde estudos de cunho florístico e taxonômico têm sido realizados nos últimos anos, apresentando avanços significativos no conhecimento da diversidade do gênero (Martins
\& Ledo 2015; Mendoza \& Cavalcanti 2015; Mendoza et al. 2015, 2016; Silva et al. 2013, 2016; Silva \& Sodré 2014; Silva 2014, 2015a, 2015b, 2016), e ampliando o número de espécies do gênero no país para cerca de 101 .

No esforço de revisar as espécies de Manihot, principalmente do bioma Cerrado, e esclarecer problemas taxonômicos latentes desde a última revisão do gênero (Rogers \& Appan 1973), este estudo acrescenta cinco novas espécies para Manihot.

As espécies aqui descritas são nativas de uma área reduzida que abrange a Serra Geral entre o Distrito Federal e o estado de Goiás, mais precisamente das áreas montanhosas da região do Alto Maranhão e Vão do Paranã, compreendidas entre 1.000 a $1.200 \mathrm{~m}$ de altitude. Esses ambientes

\footnotetext{
${ }^{1}$ Universidade de Brasília, Depto. Botânica, Campus Universitário Darcy Ribeiro, Asa Norte, C.P. 04457, 70910-970, Brasília, DF, Brasil.

${ }^{2}$ Embrapa Recursos Genéticos e Biotecnologia, Parque estação Bi logica, C.P. 02372, 70770-900, Brasília, DF, Brasil.

${ }^{3}$ Autor para correspondência: mmendoza52@yahoo.com
} 
são caracterizados pelos habitats diversificados e alta diversidade de espécies (Cavalcanti 2007).

\section{Materiais e Métodos}

A descrição das espécies aqui propostas é resultado de análises morfológicas e revisão exaustiva dos espécimes depositados nos herbários: BHCB, CEN, ESA, HB, HRCB, HEPH, HUEFS, IAN, IBGE, MBM, MG, NY, R, RB, UB, UEC, UFG, Thiers (continuamente atualizado). Observações in-situ de populações de cada espécie e sua variabilidade na natureza foram realizadas entre fevereiro 2013 e maio 2016. Ilustrações a nanquim baseados nos espécimes tipo (feitas por Darli Nuza e Pétala Gomes) e pranchas ilustrativas baseadas em fotografias de plantas vivas que destacam características de alto valor taxonômico para cada espécie são apresentados.

\section{Resultados e Discussão}

Manihot brasiliana M. Mend. \& T.B. Cavalc. sp. nov.

Tipo: BRASIL. BRASÍLIA - DISTRITO FEDERAL: Brazlândia, BR-80, ca. 1,3 km passando o trevo DF-220 sentido Padre Bernardo, em frente do povoado de Vendinha, 15'36'21's, 48 $11^{\prime} 40^{\prime \prime} \mathrm{W}, 1.118 \mathrm{~m}, 21 . \mathrm{II} .2014$, fl. e fr., $M$. Mendoza, A.A. Santos \& T.S. Reis 4150 (holótipo: CEN!; isótipos: ESA!, HUEFS!, K!, LPB!, MO!, NY!, RB!, UB!, USZ!).

Figs.: $1 ; 2$

Species nova affinis Manihot longepetiolatae Pohl, sed ab ea stipulis 2-5 mm longis, linearolanceolatis, caducis (non plus quam 6-10 mm longis, setaceis et pesistentibus), inflorescentia terminale, 3-4 racemis composita, uno longo centrale et 2-3 racemis laterais parvioribus (non axillare nec paniculata); bracteis et bracteolis $<4 \mathrm{~mm}$ longis et caducis (non $>5 \mathrm{~mm}$ longis, pesistentibus), floribus femineis gamotepalis (non dialytepalis) differt.

Subarbustos glabros, eretos, $8-20 \mathrm{~cm}$ alt, caule ereto ou raro decumbente, saindo de uma base lenhosa; ramificação ausente, raro dicotômica. Folhas não peltadas, pecioladas, alterno-espiraladas na base, alternas nos ramos superiores, face adaxial verde intenso, face abaxial esbranquiçada; estípulas caducas, profundamente bífidas, segmentos linearlanceolados, 2-5 mm compr., margem denteada, ápice atenuado; pecíolos $(1,5-) 5-8(-10) \mathrm{cm}$ compr.; lâminas membranáceas, 3-5-lobadas, raro inteiras na base da inflorescência, lobos sobrepostos nos sinus e na base; lobos centrais elípticos a estreitamente elípticos, (2,5-)4-7(-9) × $(1-) 2-3(-4) \mathrm{cm}$, margem inteira, ápice acuminado; nervação broquidódroma, nervuras primárias ligeiramente proeminentes na face abaxial, nervuras secundárias evidentes nas duas faces; lobos laterais ligeiramente reduzidos, assimétricos na base. Inflorescências multifloras, 5-8(-13) cm compr., formadas por um racemo central longo, às vezes com um ramo reduzido, e 1-2 racemos laterais curtos com flores pistiladas na base, todos saindo do mesmo ponto; brácteas caducas, lanceoladas, $3-4 \times 0,8-1 \mathrm{~mm}$, margem inteira, ápice atenuado; bractéolas caducas, reduzidas. Flores pediceladas, esverdeado-amareladas e atropurpúreas nos ápices; pedicelos das flores estaminadas 3-6(-10) $\mathrm{mm}$ compr., das flores pistiladas 5-8 $\mathrm{mm}$ compr.; flores estaminadas globoso-campanuladas, 9-12 $\times 8-10 \mathrm{~mm}$, tubo floral 6-8 $\mathrm{mm}$ compr., lobos das tépalas reflexos, 3-4 mm compr., margem lisa ou escassamente papilosa na face interna; estames didínamos; flores pistiladas gamotépalas, campanuladas, $8-10 \times 5-6 \mathrm{~mm}$, tubo floral 3,5-5 $\mathrm{mm}$ compr.; lobos das tépalas abertos, não reflexos 4,5-5 mm compr., margem levemente papilosa; ovários elípticos, pistilos com estigmas levemente amplos, brancos a creme, ápice denso-papiloso. Cápsulas subcilíndricas, 11-13 × 9-10 mm, lisas, verde-glaucas; alas ausentes, depressões lineares laterais. Sementes elípticas, $8-9 \times 3,5-4 \mathrm{~mm}$; carúncula fortemente proeminente, reniforme, ápice levemente bilobado.

Material adicional examinado: BRASIL. DISTRITO FEDERAL: Brazlândia, BR-80, ca. 900 m do trevo DF-220 sentido Padre Bernardo e $500 \mathrm{~m}$ por estrada

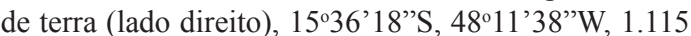
m, 2.XII.2015, fl. e fr., M. Mendoza et al. 5090 (CEN, $\mathrm{K}, \mathrm{LPB}, \mathrm{MO}, \mathrm{NY}, \mathrm{RB}, \mathrm{USZ}$ ); Rod. Brazlândia-Padre Bernardo, 1536'26"S, 48¹1'48'W, 15.I.2006, fr., J.F.B. Pastore \& E. Suganuma 1456 (CEN).

Espécie endêmica do cerrado brasiliense. Coletada até o presente apenas no Distrito Federal, em uma população reduzida na cidade satélite de Brazlândia, onde habita áreas bem preservadas de campo limpo com solo cascalhento e esbranquiçado, aos 1.115-1.120 m. Coletada com flores de dezembro a fevereiro e com frutos de janeiro a abril.

O epíteto específico alude à capital do Brasil, na zona do Distrito Federal, área geográfica onde esta espécie cresce naturalmente.

Manihot brasiliana caracteriza-se pelo hábito com aparência de roseta (na fase inicial vegetativa), pelas estípulas caducas, bífidas, com segmentos 

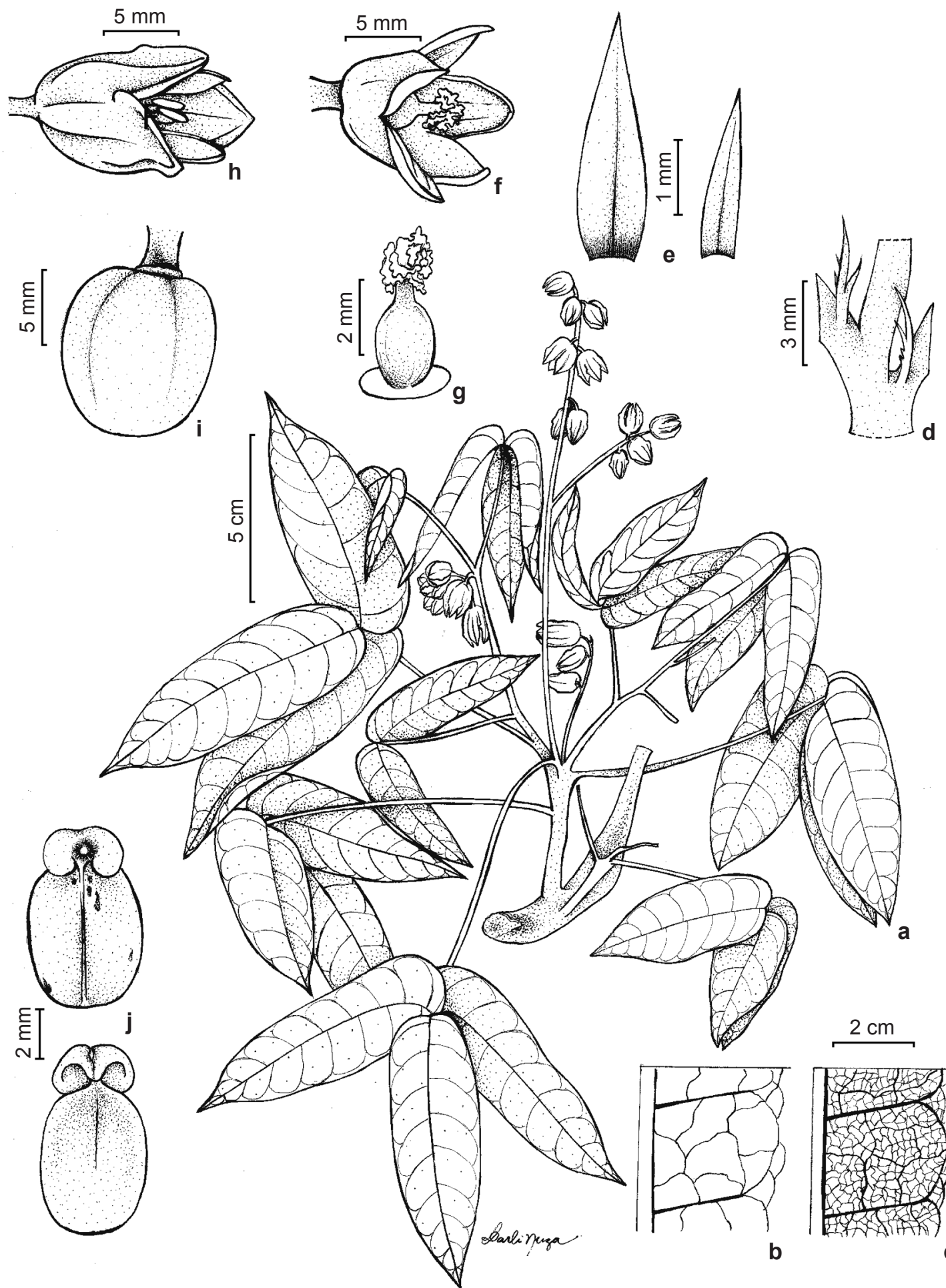

b

Figura 1 - a-j. Manihot brasiliana - a. hábito; b. detalhe de nervação foliar, face adaxial; c. detalhe de nervação foliar, face abaxial; d. estípulas; e. bráctea e bractéola (da esquerda para a direita); f. flor pistilada; g. gineceu; h. flor estaminada; i. cápsula; j. sementes (a-j. Mendoza et al. 4150).

Figure 1 - a-j. Manihot brasiliana - a. habit; b. detail of leaf venation, adaxial surface; c. detail of leaf venation, abaxial surface; d. stipules; e. bract and bracteole (from left to right); f. pistillate flower; g. gynoecium; h. staminate flower; i. capsule; j. seeds (a-j. Mendoza et al. 4150). 
linear-lanceolados de $2-5 \mathrm{~mm}$ de comprimento e margem denteada, pelas inflorescências terminais formadas por um racemo central longo e 2-3 racemos laterais curtos com flores pistiladas na base, pelas brácteas e bractéolas caducas e pelas flores pistiladas gamotépalas (Tab. 1). Manihot brasiliana é morfologicamente similar a $M$. longepetiolata Pohl, pelo hábito reduzido, folhas não peltadas e usualmente 3-lobadas, flores estaminadas globoso-campanuladas, sementes
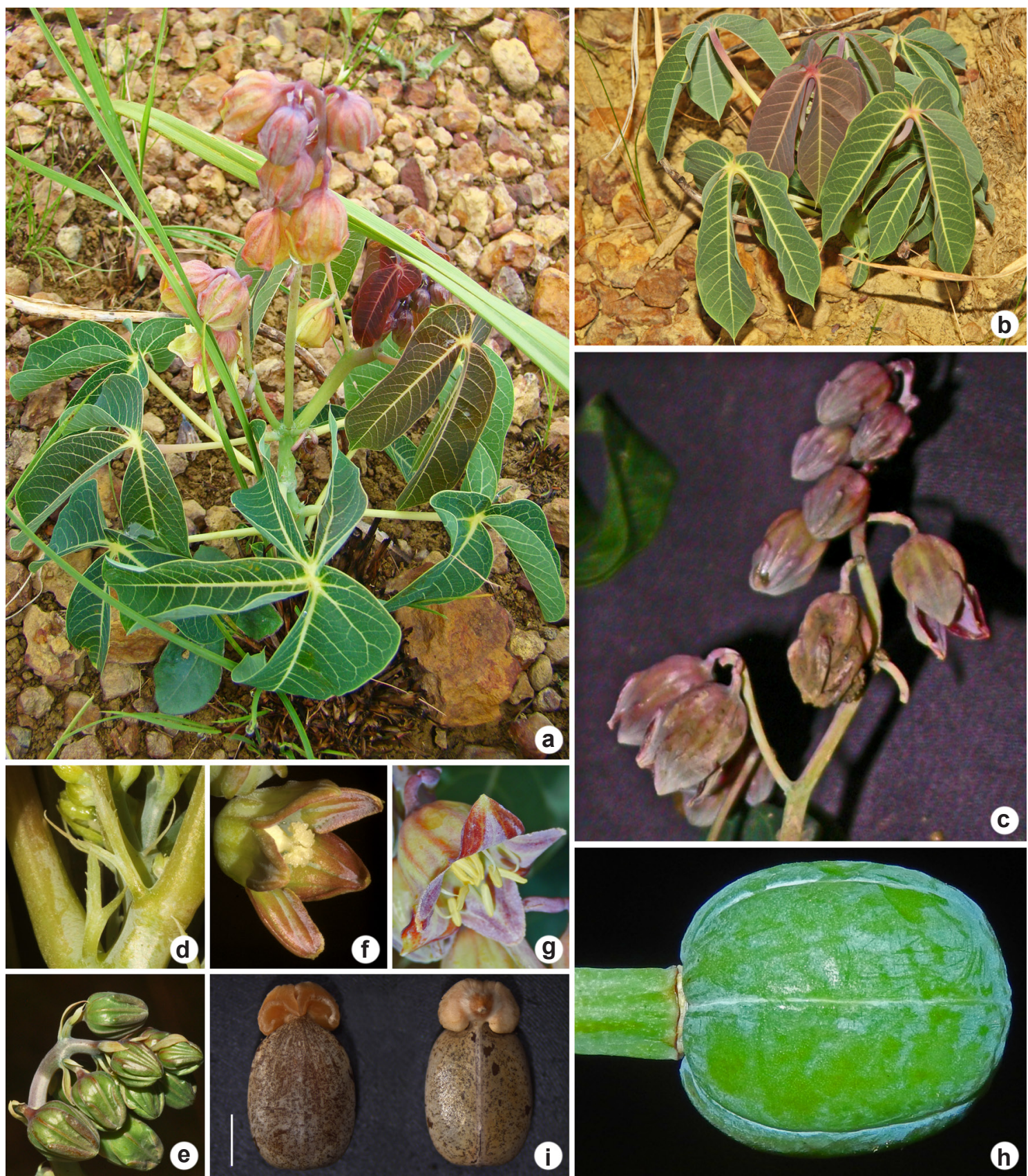

Figura 2 - a-i. Manihot brasiliana - a,b. hábito; c. inflorescência; d. estípulas; e. detalhe das brácteas e bractéolas; f. flor pistilada; g. flor estaminada; h. cápsula; i. sementes (a-i. Mendoza et al. 4150).

Figure 2 - a-i. Manihot brasiliana - a,b. habit; c. inflorescence; d. stipules; e. detail of bracts and bracteoles; f. pistillate flower; g. staminal flower; h. capsule; i. seeds (a-i. Mendoza et al. 4150). 
Tabela 1 - Comparação de caráteres morfológicos entre Manihot brasiliana, M. longepetiolata, M. congesta e M. porphyrantha. Table 1 - Comparison of morphological characters among Manihot brasiliana, M. longepetiolata, M. congesta and M. porphyrantha.

\begin{tabular}{|c|c|c|c|c|}
\hline & Manihot brasiliana & Manihot longepetiolata & Manihot congesta & Manihot porphyrantha \\
\hline Lâminas & $\begin{array}{l}\text { 3-5-lobadas, raro inteiras na } \\
\text { base da inflorescência. }\end{array}$ & $\begin{array}{l}\text { 3-lobadas normalmente } \\
\text { inteiras na base da } \\
\text { inflorescência. }\end{array}$ & $\begin{array}{l}\text { 3-lobadas, nunca } \\
\text { inteiras. }\end{array}$ & 3-lobadas, nunca inteiras. \\
\hline Estipulas & $\begin{array}{l}\text { Linear-lanceoladas, } 2-5 \mathrm{~mm} \\
\text { compr., margem denteada, } \\
\text { caducas. }\end{array}$ & $\begin{array}{l}\text { Setosas, } 6-10 \mathrm{~mm} \\
\text { compr., margem inteira, } \\
\text { persistentes. }\end{array}$ & $\begin{array}{l}\text { Linear-lanceoladas, } \\
\text { 15-25 mm compr., } \\
\text { caducas. }\end{array}$ & $\begin{array}{l}\text { Linear-lanceoladas, } \\
\text { 15-20 mm compr., } \\
\text { caducas. }\end{array}$ \\
\hline Inflorescências & $\begin{array}{l}\text { Terminal, laxa, 3-4 } \\
\text { racemosa cada. }\end{array}$ & $\begin{array}{l}\text { Lateral, laxa, panícula } \\
\text { solitária (sem racemos } \\
\text { laterais) cada. }\end{array}$ & $\begin{array}{l}\text { Terminal, congesta, } \\
\text { 3-4 racemos cada. }\end{array}$ & $\begin{array}{l}\text { Terminal, congesta ao } \\
\text { ápice dos pedúnculos, } \\
\text { 2-3 racemos, cada. }\end{array}$ \\
\hline Brácteas & $\begin{array}{l}\text { Caducas, 3-4 mm compr., } \\
\text { inteiras. }\end{array}$ & $\begin{array}{l}\text { Persistentes, } 3-4 \mathrm{~mm} \\
\text { compr., inteiras. }\end{array}$ & $\begin{array}{l}\text { Caducas, } 2-3 \mathrm{~mm} \\
\text { compr., inteiras. }\end{array}$ & $\begin{array}{l}\text { Caducas, } 2-2,5 \mathrm{~mm} \\
\text { compr., inteiras. }\end{array}$ \\
\hline Cor das flores & $\begin{array}{l}\text { Esverdeado-amareladas e } \\
\text { atropupúreas ao ápice. }\end{array}$ & Verde-arroxeadas. & $\begin{array}{l}\text { Salmão- } \\
\text { esverdeadas. }\end{array}$ & $\begin{array}{l}\text { Purpura roxo-escuras a } \\
\text { atropupúreas. }\end{array}$ \\
\hline Flores pistiladas & Gamotétalas. & Dialitépalas. & Dialitépalas. & Gamotépalas. \\
\hline Estigmas & $\begin{array}{l}\text { Levemente amplos, } \\
\text { denso-papilosos. }\end{array}$ & $\begin{array}{l}\text { Moderadamente amplos, } \\
\text { ápice denso-papilosos. }\end{array}$ & $\begin{array}{l}\text { Amplos, ápice } \\
\text { denso-papilosos. }\end{array}$ & $\begin{array}{l}\text { Amplos, ápice denso- } \\
\text { papilosos. }\end{array}$ \\
\hline $\begin{array}{l}\text { Flores } \\
\text { estaminadas }\end{array}$ & Globoso-campanuladas. & Globoso-campanuladas. & $\begin{array}{l}\text { Longo tubular- } \\
\text { campanuladas. }\end{array}$ & Globoso-campanuladas. \\
\hline
\end{tabular}

pequenas e elípticas, com carúncula fortemente proeminente e reniformes. Manihot longepetiolata difere de M. brasiliana pelas estípulas persistentes, setosas, 6-10 mm de comprimento com margem inteira, pelas inflorescências laterais, formadas por uma panícula simples e reduzida; pelas brácteas e bractéolas persistentes e pelas flores pistiladas dialitépalas, dispostas na base dos ramos primários das panículas.

Manihot congesta M. Mend. \& T.B. Cavalc. $s p$. nov.

Tipo: BRASIL. GOIÁS: Água Fria de Goiás, ca 2,3 km da GO-118, sentido Estação Repetidora Telebrasília de Roncador, mais 10 m lado direito, 14'53'7'S, 47³3'26”'W, 1.158 m, 30.X.2014, fl., M. Mendoza, T.S. Reis \& A.A. Santos 4340 (holótipo: CEN!; isótipos: K!, NY!, RB!, USZ!).

Figs. 3; 4

Species nova Manihot porphyranthae M. Mend. \& T.B. Cavalc. affinis, sed distincta inflorescentia congesta, breve, $<3,5 \mathrm{~cm}$ longa (non longiore plus quam 4-9 cm longa), floribus femineis dialytepalis (non gamotepalis), floribus masculis valde tubulo-campanulatibus (non globosis-campanulatis).
Subarbustos glabros, eretos, $8-20 \mathrm{~cm}$ alt., caule ereto solitário saindo de uma base lenhosa, raro um ramo reduzido saindo perto da base; ramificação ausente. Folhas não peltadas, pecioladas, alterno-espiraladas, congestas, com aparência de roseta, face adaxial verde escura, face abaxial glauca; estípulas caducas, linearlanceoladas, $4-5 \mathrm{~mm}$ compr., margem inteira, ápice atenuado; pecíolos $(2-) 5-8(-10) \mathrm{cm}$ compr.; lâminas membranáceas, 3-lobadas, lobos moderadamente sobrepostos nos sinus e na base; lobos centrais elípticos, $(2,5-) 4-6(-8) \times$ $(1-) 2-3(-4) \mathrm{cm}$, margem inteira, ápice acuminado; nervação broquidódroma, nervuras primárias ligeiramente proeminentes na face abaxial, nervuras secundárias evidentes nas duas faces; lobos laterais ligeiramente reduzidos, assimetrias na base. Inflorescências multifloras, congestas, reduzidas, 1,5-3,5 cm compr., formadas por um racemo central longo e 1-2 racemos laterais curtos, todos saindo do mesmo ponto; brácteas caducas, lanceoladas, $2-3 \times 0,8-1 \mathrm{~mm}$, margem inteira, ápice atenuado; bractéolas caducas, reduzidas. Flores pediceladas, salmão-esverdeadas, botões mais escuros; pedicelos das flores estaminadas 2-3 $\mathrm{mm}$ compr., das flores pistiladas 5-8 $\mathrm{mm}$ compr.; 


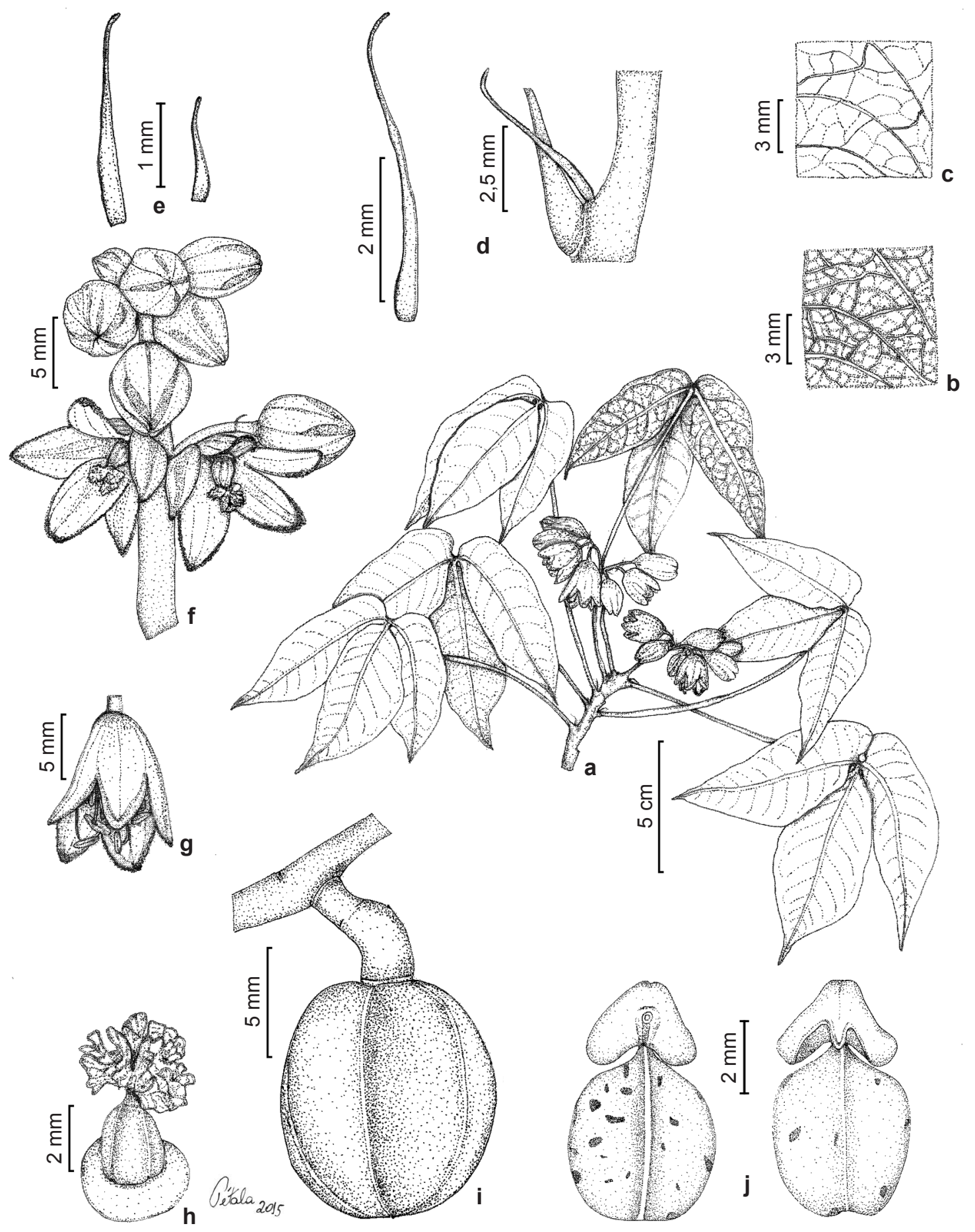

Figura 3 - a-j. Manihot congesta - a. hábito; b. detalhe de nervação foliar, face abaxial; c. detalhe de nervação foliar, face adaxial; d. estípulas; e. bráctea e bractéola (da esquerda para a direita); f. inflorescência com flores pistiladas; g. flor estaminada; h. gineceu; i. cápsula; j. sementes (a-h. Mendoza et al. 4340; i,j. Mendoza et al. 4112).

Figure 3 - a-j. Manihot congesta - a. habit; b. detail of leaf venation, abaxial surface; c. detail of leaf venation, adaxial surface; $d$. stipules; e. bract and bracteole (from left to right); f. inflorescence with pistilate flowers; g. staminate flower; h. gynoecium; i. capsule; j. seeds (a-h. Mendoza et al. 4340; i,j. Mendoza et al. 4112). 
flores estaminadas tubular-campanuladas, 9-10 $\times$ 5-6 mm, tubo floral 6-7 mm compr., lobos das tépalas levemente abertos, não reflexos, 3-4 mm compr., margem inflexa, papilosa na face interna; estames didínamos; flores pistiladas dialitépalas, campanuladas, levemente abertas, $6-8 \times 5-6$ $\mathrm{mm}$, tépalas levemente reflexas, margem papilosa na face interna; ovário subcônico, pistilos com estigmas amplos, rosa-salmão, ápice densopapiloso. Cápsulas subglobosas, 10-12 × 9-10 $\mathrm{mm}$, lisas, verde-glaucas; alas ausentes, depressões lineares laterais. Sementes subelípticas, 6-7 $\times$

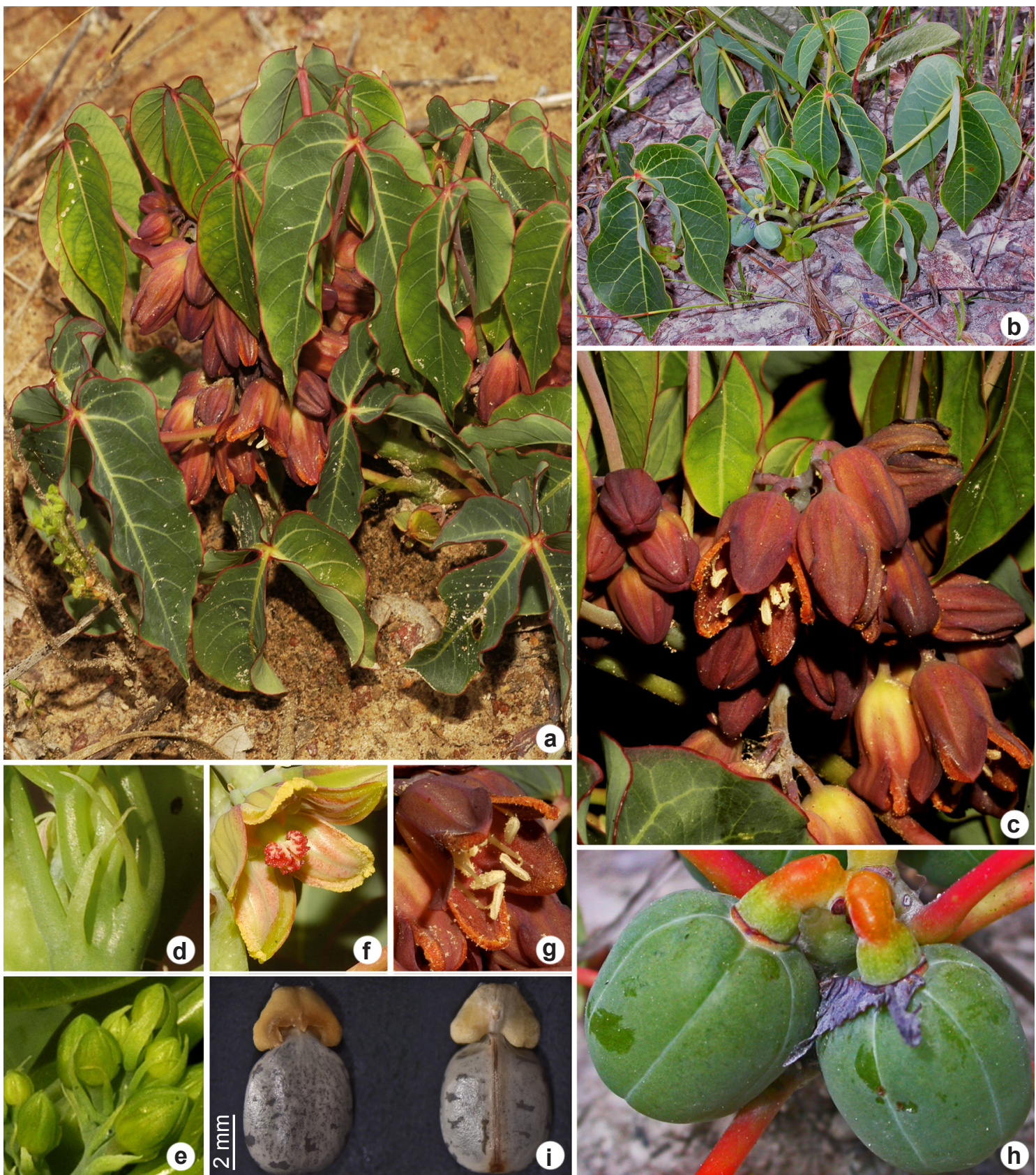

Figura 4 - a-i. Manihot congesta - a-b. hábito; c. inflorescência; d. estípulas; e. detalhe das brácteas e bractéolas; f. flor pistilada; g. flor estaminada; h. cápsula; i. sementes (a-g. Mendoza et al. 4340; h,i. Mendoza et al. 4112).

Figure 4 - a-i. Manihot congesta - a-b. habit; c. inflorescence; d. stipules; e. detail of bracts and bracteoles; f. pistillate flower; g. staminate flower; h. capsule; i. seeds (a-g. Mendoza et al. 4340; h,i. Mendoza et al. 4112). 
4,5-5 mm; carúncula fortemente proeminente, reniforme, ápice rotundo.

Material adicional examinado: BRASIL. GOIÁS: Água Fria de Goiás, ca. 2,3 km da GO-118 por estrada de terra para a Estação Repetidora Telebrasília de Roncador, mais $200 \mathrm{~m}$ lado esquerdo, área do córrego, 1453'4”S, 47³3'15'W, 1.156 m, 4.II.2014, fr., M. Mendoza et al. 4112 (CEN, K, NY, USZ); Estação Repetidora Telebrasília de Roncador, 1.200 m, 30.XI.1992, fr., G. Hatschbach \& M. Hatschbach 58320 (CEN, MBM).

Endêmica do estado de Goiás, onde ocorre em áreas montanhosas, em vegetação preservada de campo limpo, campo sujo, em áreas planas ou de encostas moderadas, em solo cascalhento esbranquiçado, aos 1.150-1.200 m. Coletada com flores de outubro a novembro e com frutos de novembro a março.

O epiteto específico faz alusão à inflorescência com flores numerosas e densamente dispostas em racemos reduzidos.

Manihot congesta pode ser reconhecida pelas inflorescências fortemente reduzidas, congestas, 1,5-3,5 cm de comprimento, pelas flores pistiladas dialitépalas e flores estaminadas longo-tubulosas, campanuladas. Manihot congesta é morfologicamente similar a $M$. prophyrantha M. Mend. \& T.B. Cavalc., pelo hábito reduzido, folhas 3-lobadas, estípulas linear-lanceoladas de margem inteira, brácteas e bractéolas caducas e reduzidas, frutos subglobosos e não alados. Manihot prophyrantha difere de $M$. congesta pelas inflorescências laxas, 4-9 cm comprimento, concentradas na região distal dos pedúnculos, pelas flores pistiladas gamotépalas, flores estaminadas globoso-campanuladas e flores de cor atropurpúrea (Tab. 1).

Manihot incisa M. Mend. \& T.B. Cavalc. sp. nov. Tipo: BRASIL. GOIÁS: Água Fria de Goiás, Fazenda Horizonte, ca. 9 km do trevo GO-230, indo pela trilha para Central Genética Umburana, mais $500 \mathrm{~m}$ à esquerda e logo $500 \mathrm{NW}, 15^{\circ} 36^{\prime} 23^{\prime \prime} \mathrm{S}$, 4811'46"W, 1.027 m, 20.XI.2015, fl., M. Mendoza, M.F. Simon, T.K.M Arquelão \& R.C. Pires 5076 (holótipo: CEN!; isótipos: K!, LPB!, NY!, RB!, UB!, USZ!).

Figs. 5; 6

Species nova debilis rosularis affinis Manihot nogueirae Allem, sed glabrerrima (non manifeste tomentosa), stipulis pinnatifidis segmentis linearibus (non setactis bi-trifidis), inflorescentia laxa (non congesta), floribus longis, angustis tubulo-campanulatis, (non brevibus globosocampanulatis), antheris similibus magnitudis (non didymanous) differt.
Subarbustos glabros, eretos, 10-25 cm alt., caule solitário ereto saindo de uma base lenhosa; ramificação ausente ou às vezes 2-3 saindo próximo à base. Folhas estreito peltadas, pecioladas, alterno-espiraladas, congestas, com aparência de roseta, face adaxial verde, face abaxial glauca; estípulas persistentes, linearpinatífidas, (10-)15-27 mm compr., ou às vezes 2-3 segmentos linear-pinatífidos saindo do mesmo ponto, margem denteada, ápice linearagudo; pecíolos (2,5-)6-10(-15) cm compr.; lâminas membranáceas, 7-9-lobadas, lobos não sobrepostos; lobos centrais incisos a pinadamente lobulados, $(2-) 3-4,5(-5,5) \times 1-2(-3,5) \mathrm{cm}$, lóbulos inteiros ou às vezes $1-3$-denteados, ápice acuminado-ciliado; nervação craspedódroma, nervuras primárias levemente proeminentes na face abaxial, nervuras secundárias evidentes nas duas faces; lobos laterais gradualmente reduzidos. Inflorescências paucifloras, laxas, reduzidas, 3-6 cm compr., formada por um racemo central longo e 1-2 racemos laterais curtos, todos saindo do mesmo ponto; brácteas persistentes, linearlanceoladas, 8-13 × 0,5-1 mm, margem inteira, raro 1-3-denteada, ápice atenuado, bractéolas persistentes, reduzidas. Flores pediceladas, salmão intenso a laranja-salmão, mais escuras em botão; pedicelos das flores estaminadas 10-15 mm compr., das flores pistiladas 4-6 mm compr.; flores estaminadas longo tubular-campanuladas, $12-15 \times 8-10 \mathrm{~mm}$, tubo floral 8-10 mm compr., lobos das tépalas suavemente abertos a reflexos, 4-5 mm compr., margem lisa; estames todos do mesmo tamanho; flores pistiladas gamotépalas, campanuladas, abertas 9-11 ×5-6 mm, tubo floral 5-6 mm compr.; lobos das tépalas suavemente abertos a reflexos, 4-5 mm compr., margem lisa; ovários elípticos, pistilos com estigmas reduzidos, salmão a rosado intenso, ápice levemente papiloso. Cápsulas subcilíndricas a globosas, 8-9 × 7-8 mm, lisas, verde-glaucas; alas ausentes, depressões laterais finas. Sementes elípticas 6-7 × 3,5-4 mm; carúncula fortemente proeminente, reniforme, ápice rotundo, bilobado.

Material adicional examinado: BRASIL. GOIÁS: Água Fria de Goiás, Fazenda Horizonte, ca. $9 \mathrm{~km}$ do trevo GO-230, indo pela trilha para Central Genética Umburana, mais $500 \mathrm{~m}$ a esquerda e logo $500 \mathrm{~m} \mathrm{NW}$, 15'54'36"S, 4748'46"W, 1.002 m, 5.VI.2015, fr., $M$. Mendoza et al. 5023 (CEN, USZ); GO-237, ca. 37,3 km do trevo GO-118, sentido Niquelândia, 1452'42”S, 4749'15'W, 1.012 m, 13.V.2016, fl., M. Mendoza et al. 5255 (CEN, K, LPB, NY, RB, USZ); GO-237, ca. $38,5 \mathrm{~km}$ do trevo GO-118, e entrando ca. $4,2 \mathrm{~km}$ sentido 


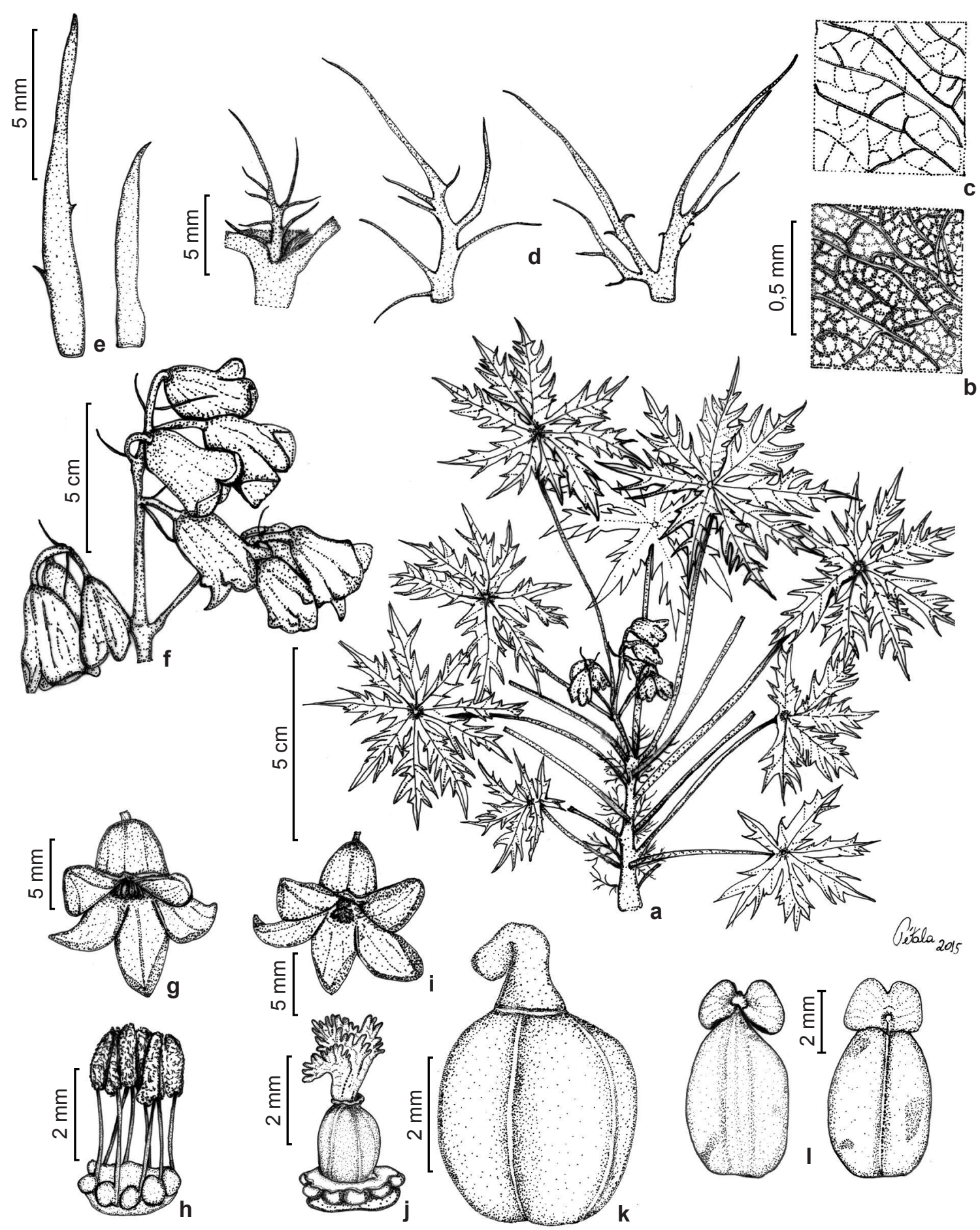

Figura 5 - a-1. Manihot incisa - a. hábito; b. detalhe de nervação foliar, face abaxial; c. detalhe de nervação foliar, face adaxial; d. estípulas mostrando forte variação morfológica; e. bráctea e bractéola (da esquerda para a direita); f. inflorescência; g. flor estaminada; h. estames todos do mesmo tamanho; i. flor pistilada; j. gineceu; k. cápsula; 1 . sementes (a-j. Mendoza et al. 5076; k,1. Mendoza et al. 5023).

Figure 5 - a-1. Manihot incisa - a. habit; b. detail of leaf venation, abaxial surface; c. detail of leaf venation, adaxial surface; d. stipules showing strong morphologic variation; e. bract and bracteole; f. inflorescence; g. staminal flower; h. stamens all of the same size; i. pistillate flower; j. gynoecium; k. capsule; 1. seed. (a-j. Mendoza et al. 5076; k,1. Mendoza et al. 5023). 
Fazenda Bálsamo, 1454'10”S, 4751'20”W, 1.038 m, 20.XI.2015, fl., M. Mendoza et al. 5083 (CEN, K, NY, USZ).

Espécie endêmica do estado de Goiás. Conhecida de zonas montanhosas, áreas preservadas de campo sujo e cerrado ralo, normalmente em encostas moderadas a pronunciadas, até em locais planos, em solo cascalhento e esbranquiçado, aos 1.000-1.050 m. Coletada com flores de outubro a janeiro e com frutos de dezembro a junho.

$\mathrm{O}$ epíteto específico alude às folhas com lobos incisos.
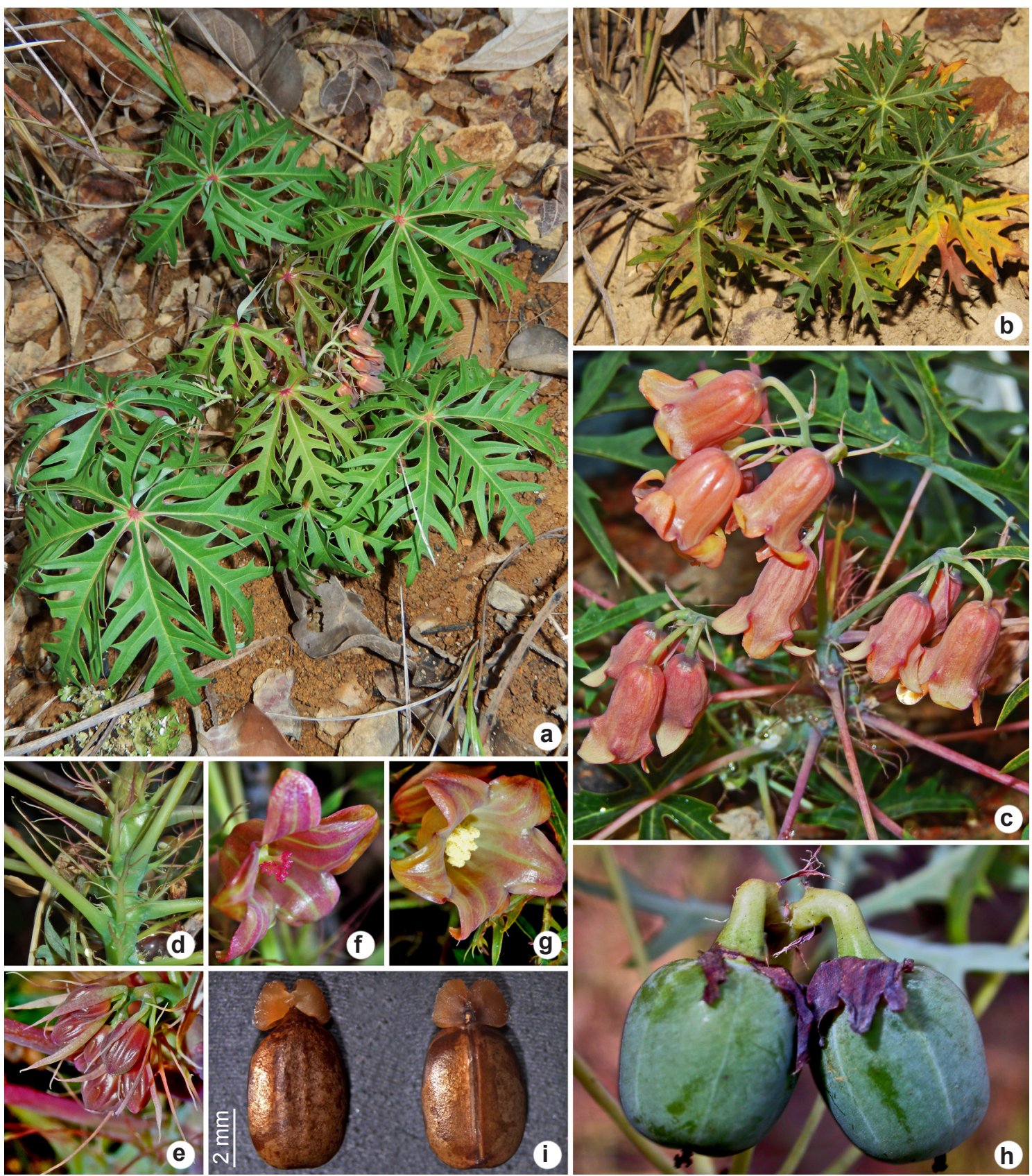

Figura 6 - a-i. Manihot incisa - a,b. hábito; c. inflorescência; d. estípulas; e. detalhe das brácteas e bractéolas; f. flor pistilada; g. flor estaminada; h. cápsula; i. sementes (a,c-g. Mendoza et al. 5076; b,h,i. Mendoza et al. 5023). Figure 6 - a-i. Manihot incisa - a,b. habit; c. inflorescence; d. stipules; e. detail of bracts and bracteoles; f. pistillate flower; g. staminate flower; h. capsule; i. seeds (a,c-g. Mendoza et al. 5076; b,h,i. Mendoza et al. 5023). 
Manihot incisa é caracterizada pelo porte pequeno, hábito delicado similar a roseta e completamente glabro, pelas estípulas linearpinatífidas, pelas inflorescências laxas com flores estaminadas longas, tubular-campanuladas, com estames todos do mesmo tamanho. Manihot incisa é morfologicamente similar a M. nogueirae Allem pelo hábito com folhas similar a roseta, estípulas persistentes, folhas lobadas com lobos incisos, flores pistiladas gamotépalas e frutos não alados. Manihot nogueirae se diferencia pelo indumento denso-tomentoso, estípulas nunca pinatífidas, inflorescências congestas, flores estaminadas globoso-campanuladas, androceu didínamos (Tab. 2).

Manihot pinatiloba M. Mend. \& T.B. Cavalc. sp. nov.

Tipo: BRASIL. GOIÁS: Água Fria de Goiás, ca 2,3 km da GO-118 sentido Estação Repetidora Telebrasília de Roncador, mais 15 m lado direito,
1453'9"S, 47³3'23”'W, 1.158 m, 30.X.2014, fl., M. Mendoza, T.S. Reis \& A.A. Santos 4341 (holótipo: CEN!; isótipos: LPB!, NY!, RB!, USZ!).

Figs. $7 ; 8$

Species nova Manihot attenuatae Müll. Arg., affinis sed distincta foliis pinnatilobatis (non integris), ca. 40 venis secundaris instructis, irregulariter dispositis interdum ad angulum $45^{\circ}$, interdum $90^{\circ}$, et interdum $110^{\circ}$ patentibus (non ca. 50-65 fere rectangularibus, ad subangulum 80-90 patentibus), estipulis linearo-lanceolatis, plus quam 8-15 mm longis et dentatis (non setaceis, $<5$ mm longis nec integra), inflorescentia 3-4-racemis (non uni-racema).

Subarbustos glabros, eretos, 10-25 cm alt., caule solitário ereto saindo de uma base lenhosa; ramificação ausente, ou raro um ramo pequeno saindo próximo à base. Folhas não peltadas, sésseis, rosuladas, face adaxial verde-pálido, face abaxial glauca, com uma linha púrpura na margem; estípulas tardio-caducas, linear-lanceoladas,

Tabela 2 - Diferencias morfológicas entre Manihot incisa em relação a M. nogueirae, e Manihot pinatiloba em relação a M. attenuata.

Table 2 - Morphological differences between Manihot incisa in relation to M. nogueirae, and between Manihot pinatiloba and M. attenuata.

\begin{tabular}{|c|c|c|c|c|}
\hline & Manihot incisa & Manihot nogueirae & Manihot pinatiloba & Manihot attenuata \\
\hline Indumento & Glabra em todas suas partes & $\begin{array}{l}\text { Densamente tomentosa } \\
\text { em todas suas partes }\end{array}$ & $\begin{array}{l}\text { Glabra em todas suas } \\
\text { partes }\end{array}$ & $\begin{array}{l}\text { Glabra em todas suas } \\
\text { partes }\end{array}$ \\
\hline Estipulas & $\begin{array}{l}\text { Linear-pinatifidas simples } \\
\text { ou às vezes } 2-3 \text {-sectadas, } \\
\text { segmentos linear-pinatifidos, } \\
10-27 \text { mm compr. }\end{array}$ & $\begin{array}{l}\text { Setáceas simples ou } \\
\text { 2-3-sectadas, } \\
\text { 10-27 mm compr., } \\
\text { margem inteira }\end{array}$ & $\begin{array}{l}\text { Linear-lanceoladas, } \\
\text { 8-15 mm compr., } \\
\text { margem dentada }\end{array}$ & $\begin{array}{l}\text { Setáceas, }<5 \mathrm{~mm} \\
\text { compr., margem } \\
\text { inteira }\end{array}$ \\
\hline $\begin{array}{l}\text { Inserção foliar e } \\
\text { lâmina }\end{array}$ & $\begin{array}{l}\text { Brevemente peltadas, } \\
\text { 7-9-lobadas }\end{array}$ & $\begin{array}{l}\text { Não peltadas, } \\
\text { 5-9-lobadas }\end{array}$ & $\begin{array}{l}\text { Não peltadas, } \\
\text { pinadamente 3-7-lobadas }\end{array}$ & Não peltadas, inteiras \\
\hline $\begin{array}{l}\text { Folhas, nervuras } \\
\text { secundarias }\end{array}$ & $\begin{array}{l}\text { Poucas (menos de } 20 \text { ) } \\
\text { formando ângulos, ca. } 45^{\circ} \\
\text { em relação às primárias }\end{array}$ & $\begin{array}{l}\text { Poucas (menos de } 20 \text { ) } \\
\text { formando ângulos, } \\
\text { ca. } 45^{\circ} \text { em relação às } \\
\text { primárias }\end{array}$ & $\begin{array}{l}\text { Numerosas (menos de } \\
\text { 40) formando ângulos } \\
\text { desordenados em relação } \\
\text { ás primárias }\end{array}$ & $\begin{array}{l}\text { Muito numerosos }(50- \\
60) \text { formando ângulos } \\
\text { entre } 80-90^{\circ} \mathrm{em} \\
\text { relação ás primarias }\end{array}$ \\
\hline Inflorescências & $\begin{array}{l}\text { Laxas, pauciflora, } \\
2-3 \text { racemos cada }\end{array}$ & $\begin{array}{l}\text { Congestas, pauciflora, } \\
\text { 3-4 racemos cada }\end{array}$ & $\begin{array}{l}\text { Laxas, multiflora, } \\
\text { 3-4 racemos cada }\end{array}$ & $\begin{array}{l}\text { Laxas, multiflora, } \\
\text { racemo solitário }\end{array}$ \\
\hline Brácteas & $\begin{array}{l}\text { Linear-lanceoladas, inteiras, } \\
\text { 8-13 mm compr. }\end{array}$ & $\begin{array}{l}\text { Estreitamente elípticas } \\
3 \text { denteado-sectadas no } \\
\text { ápice, } 8-15 \mathrm{~mm} \text { compr. }\end{array}$ & $\begin{array}{l}\text { Linear-lanceoladas, } \\
\text { inteiras, 2-3 mm compr. }\end{array}$ & $\begin{array}{l}\text { Linear-lanceoladas, } \\
\text { inteiras, } 4-5 \mathrm{~mm} \\
\text { compr. }\end{array}$ \\
\hline $\begin{array}{l}\text { Flores } \\
\text { estaminadas }\end{array}$ & $\begin{array}{l}\text { Longas tubular- } \\
\text { campanuladas }\end{array}$ & Globoso-campanuladas & $\begin{array}{l}\text { Curtas globoso- } \\
\text { campanuladas }\end{array}$ & $\begin{array}{l}\text { Curtas globoso- } \\
\text { campanuladas }\end{array}$ \\
\hline Estames & Do mesmo tamanho & Didínamos & Didínamos & Didínamos \\
\hline Frutos & Subcilíndricos & Cônicos & Subcilíndricos & Não visto \\
\hline
\end{tabular}




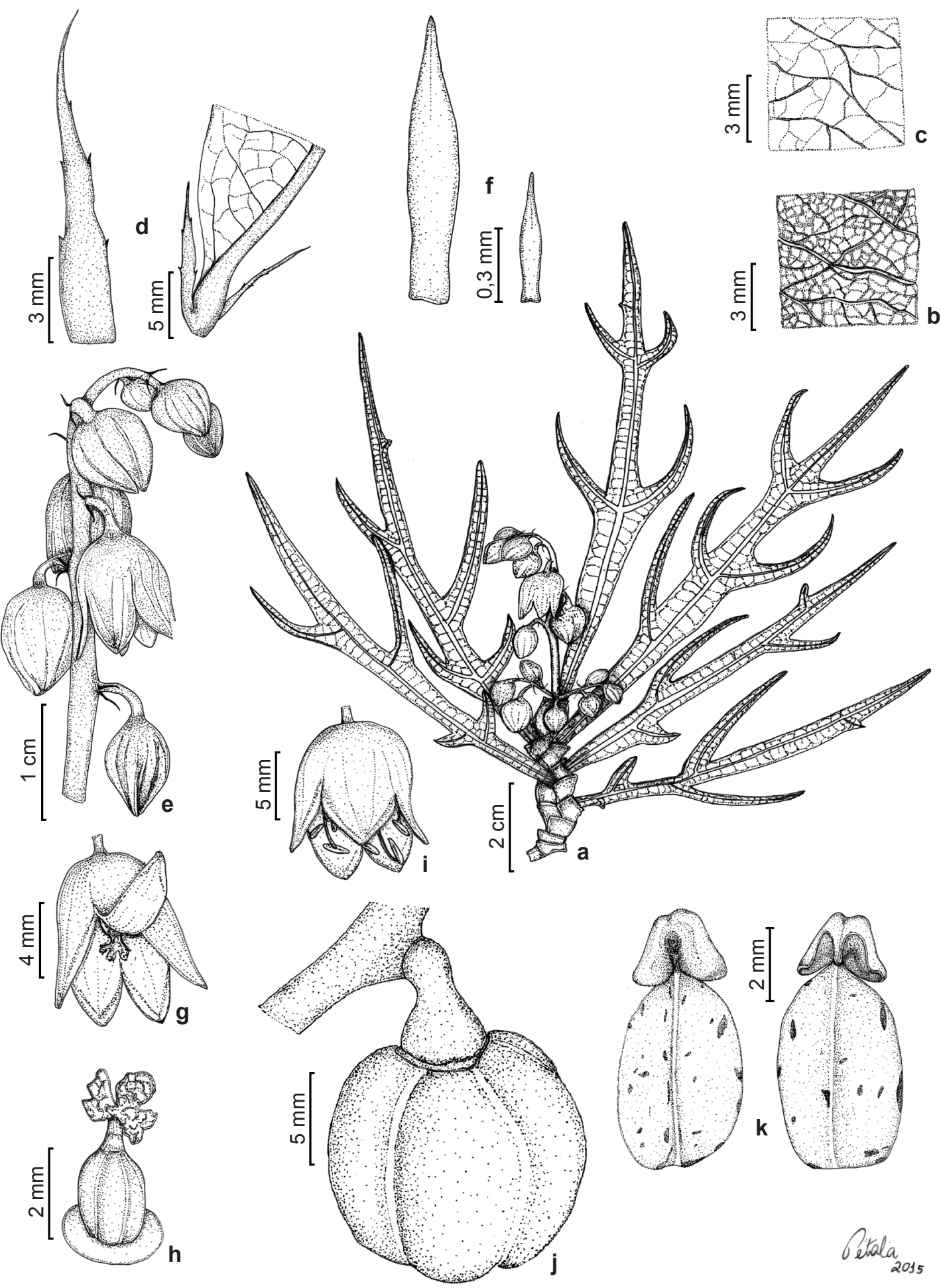

Figura 7 - a-k. Manihot pinatiloba - a. hábito; b. detalhe de nervação foliar, face abaxial; c. detalhe de nervação foliar, face adaxial; d. estípulas; e. inflorescência; f. bráctea e bractéola (da esquerda para a direita); g. flor pistilada; h. gineceu; i. flor estaminada; j. cápsula; k. sementes (a-h. Mendoza et al. 4341; i-k. Mendoza et al. 4107).

Figure 7 - a-k. Manihot pinatiloba - a. habit; b. detail of leaf venation, abaxial surface; c. detail of leaf venation, adaxial surface; $d$. stipules; e. inflorescence; f. bract and bracteole (from left to right); g. pistillate flower; h. gynoecium; i. staminate flower; j. capsule; k. seeds (a-h. Mendoza et al. 4341; i-k. Mendoza et al. 4107). 
(8-)10-15 mm compr., margem denteada, ápice atenuado; lâminas membranáceas, base decurrente, pinadamente 3-7-lobadas, $(8,5-) 12-20(-25)$ $\times(0,8-) 1-2(-2,5) \mathrm{cm}$, lobo apical usualmente pandurado, margem inteira, ápice agudo; nervação camptódodroma, nervuras primárias proeminentes na face abaxial; nervuras secundárias, $<40$ na lâmina central, formando ângulos desordenados em relação às primárias; lobos laterais muito variáveis em comprimento, $1,5-10 \mathrm{~cm}$, margem inteira. Inflorescências multifloras, laxas, 5-10 cm compr., formada por um racemo central longo

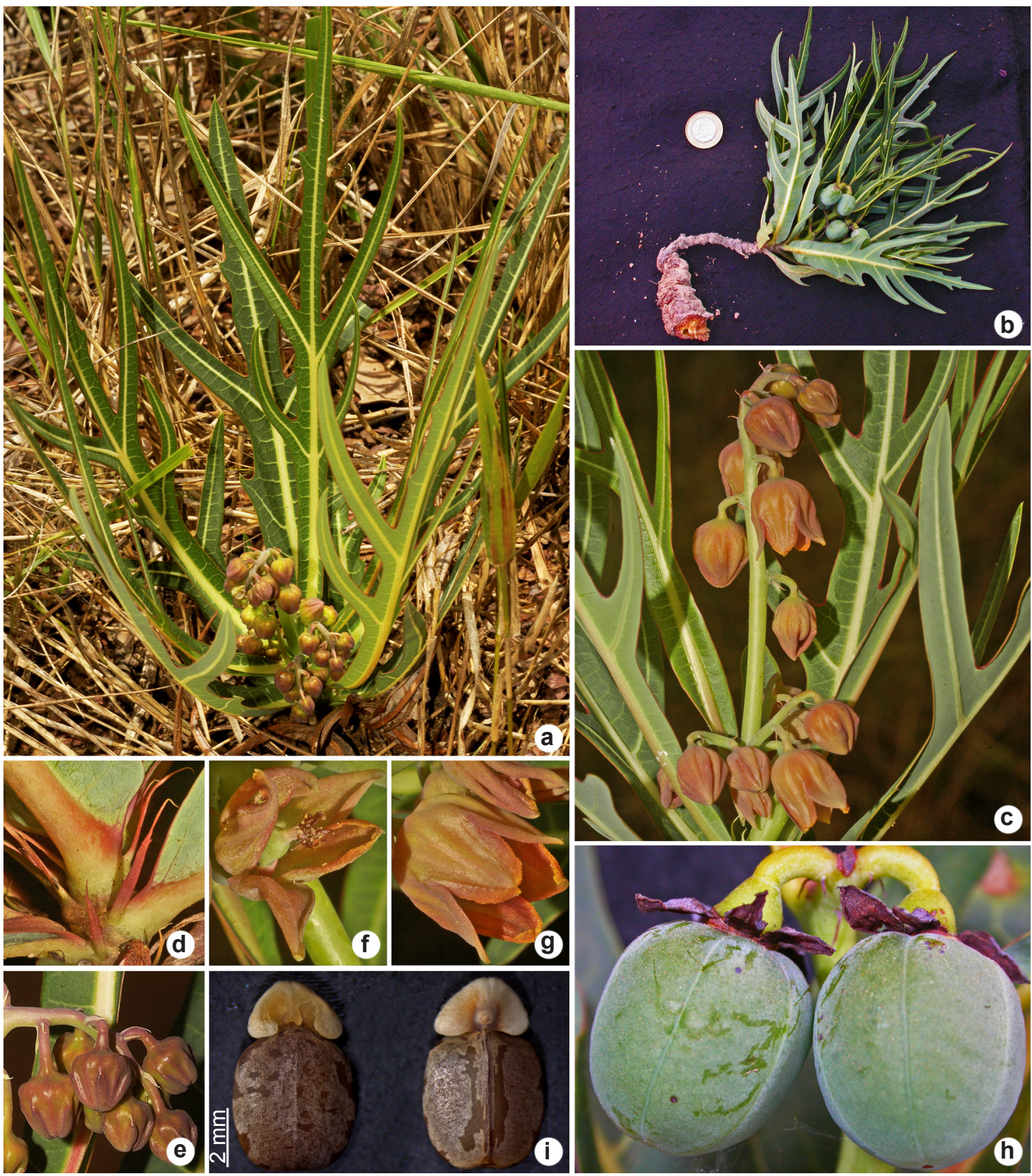

Figura 8 - a-i. Manihot pinatiloba - a,b. hábito; c. inflorescência; d. estípulas; e. detalhe das brácteas e bractéolas; f. flor pistilada; g. flor estaminada; h. cápsula; i. sementes (a,c-g. Mendoza et al. 4341; b,h,i. Mendoza et al. 4107). Figure 8 - a-i. Manihot pinatiloba - a,b. habit; c. inflorescence; d. stipules; e. detail of bracts and bracteoles; f. pistillate flower; g. staminate flower; h. capsules; i. seeds (a,c-g. Mendoza et al. 4341; b,h,i. Mendoza et al. 4107). 
e 2-3 racemos laterais curtos, todos saindo do mesmo ponto; brácteas tardio-caducas, linearlanceoladas, 2-3 × 0,3-0,5 mm, margem inteira, raro 1-3-denteada, ápice atenuado; bractéolas tardio-caducas, reduzidas. Flores pediceladas, salmão intenso a laranja-salmão, mais escuras em botão; pedicelos das flores estaminadas 3-5 mm compr., nas flores pistiladas 5-6 mm compr.; flores estaminadas curtas, globoso-campanuladas, 8-10 $\times$ 6-8 mm, tubo floral 3-4 mm compr., lobos das tépalas abertos a suavemente reflexos, 5-6 mm compr., margem inflexa, papilosa na face interna; estames didínamos; flores pistiladas dialitépalas, campanuladas, abertas, 5-7 × 5-6 mm, tépalas levemente reflexas, margem inflexa e papilosa na face interna; ovários ovoides, pistilos com estigmas amplos, salmão-purpúreos, ápice discretamente papiloso. Cápsulas subcilíndricas, 11-13 × 11-12 $\mathrm{mm}$, lisas, verde-glaucas; alas ausentes, depressões laterais finas. Sementes elípticas, 6-7 × 4-4,5 mm; carúncula fortemente proeminente, reniforme, ápice obtuso.

Material adicional examinado: BRASIL. GOIÁS: Região do Maranhão Superior, IX.1892, fl., E. Ule 782 (R). Água Fria de Goiás, ca $1,5 \mathrm{~km}$ da GO-118 por estrada de terra para a Estação Repetidora Telebrasília de Roncador, e entrando, ca. $50 \mathrm{~m}$ ao lado esquerdo, 14'53'1"S, 47'33'49'W, 1.018 m, 4.II.2014, fr., $M$. Mendoza et al. 4107 (CEN, UB, USZ); ca 2,3 km da GO-118 por estrada de terra para a Estação Repetidora Telebrasília de Roncador, e entrando, ca. $15 \mathrm{~m}$ lado direito, 1453'9”'S, 47³3'22”W, 1.166 m, 4.II.2014, fr., M. Mendoza et al. 4114 (CEN, USZ); ca 52,5 km na GO-118 passando São Gabriel para São João d'Aliança,

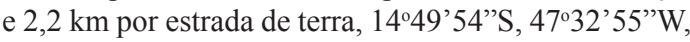
1.083 m, 10.II.2014, fr., M. Mendoza et al. 4120 (CEN); Estação Repetidora Telebrasília de Roncador, 1.000 m, 30.XI.1992, fr., G. Hatschbach \& M. Hatschbach 58296 (CEN, MBM). São João d'Aliança, $1 \mathrm{~km}$ à esquerda depois da Fazenda Atos Hotel, para Estrada do Vãozinho, 17.XII.2009, fr, R.G. Chacón \& J.E. Faria Jr. 585 (UB, CEN). São João d'Aliança - Alto Paraíso, GO-118, ca. 2 km passando o Hotel Fazenda Atos, e 3,8 km na estrada para Vãozinho, 14³9'27,3”S, 47³2'11,1'W, 1.023 m, 10.II.2014, fr., M. Mendoza et al. 4121 (CEN, RB, USZ).

Espécie endêmica de Goiás, ocorrendo em zona montanhosa, áreas preservadas de campo limpo, campo sujo, cerrado ralo e áreas de transição, bem como em áreas planas ou encostas moderadas a fortemente pronunciadas, em solo rochoso ou cascalhento, aos 1.000-1.170 m. Coletada com flores em outubro a dezembro e com frutos de novembro a abril.

O epíteto específico deriva das folhas pinadamente lobadas, um carácter evidente e distintivo deste táxon em relação a todas as espécies do gênero.

Manihot pinatiloba é caracterizada pelas folhas pinadamente 3-7-lobadas, com $<40$ nervuras secundárias na lâmina central, formando ângulos desordenados em relação às nervuras primárias, pelas estípulas linear-lanceoladas com margem denteada e pelas inflorescências formadas por um racemo central longo e 2-3 racemos laterais reduzidos. Morfologicamente, M. pinatiloba é similar a $M$. attenuata Müll. Arg. pelo porte reduzido, com folhas sésseis, em roseta, pelas folhas sésseis, brácteas e bractéolas inteiras e flores pediceladas. Manihot attenuata difere de M. pinatiloba pelas folhas inteiras com 50-60 nervuras secundárias formando ângulos de 80-90 em relação às nervuras primárias, estípulas setáceas de margem inteira e inflorescência em racemos solitários (Tab. 2).

Manihot porphyrantha M. Mend. \& T.B. Cavalc. sp. nov.

Tipo: BRASIL. GOIÁS: Niquelândia, Norte de Padre Bernardo, ca $44 \mathrm{~km}$ do trevo GO-230, 14'50'15'S, 48¹3'29'W, 1.080 m, 4.XI.2014, fl., M. Mendoza, A.A. Santos \& T.S. Reis 4368 (holótipo: CEN!; isótipos: K!, NY!, RB!, UB!, USZ!).

Figs. 9; 10

Species nova affinis Manihot congesta $M$. Mend. \& T.B. Cavalc. sed ab ea floribus in racemis disposita et congesta at apicem (non congestis at basem), floribus atropurpureis vel nigricantibus et globoso-campanulatis (non violaceo-pruinosis nec tubulato-campanulatis), floribus femineis gamotepalis (non dialytepalis), stigma magno, in apicem papillilossimo (non parvo nec pauciloba).

Subarbustos eretos, 15-25 cm alt., caule ereto, saindo de uma base lenhosa; ramificação ausente, raro um ramo pequeno saindo próximo à base. Folhas não peltadas, pecioladas, alternoespiraladas, glabras, falcadas em vista lateral, face adaxial verde pálido, face abaxial glauca; estípulas caducas, setáceas, 1,5-2 mm compr., margem denteada, ápice atenuado, glabras; pecíolos (3-)6-12(-15) cm compr.; lâminas membranáceas, 3-lobadas, lobos fortemente sobrepostos nos sinus e na base; lobos centrais elípticos, (4-)5-8 × (1,5),5-3,5 cm, margem inteira, ápice acuminadoatenuado, glabros; nervação camptódodroma, nervuras primárias proeminentes na face abaxial, nervuras secundárias evidentes nas duas faces; lobos laterais suavemente reduzidos, assimétricos na base. Inflorescências multifloras, flore agrupadas 


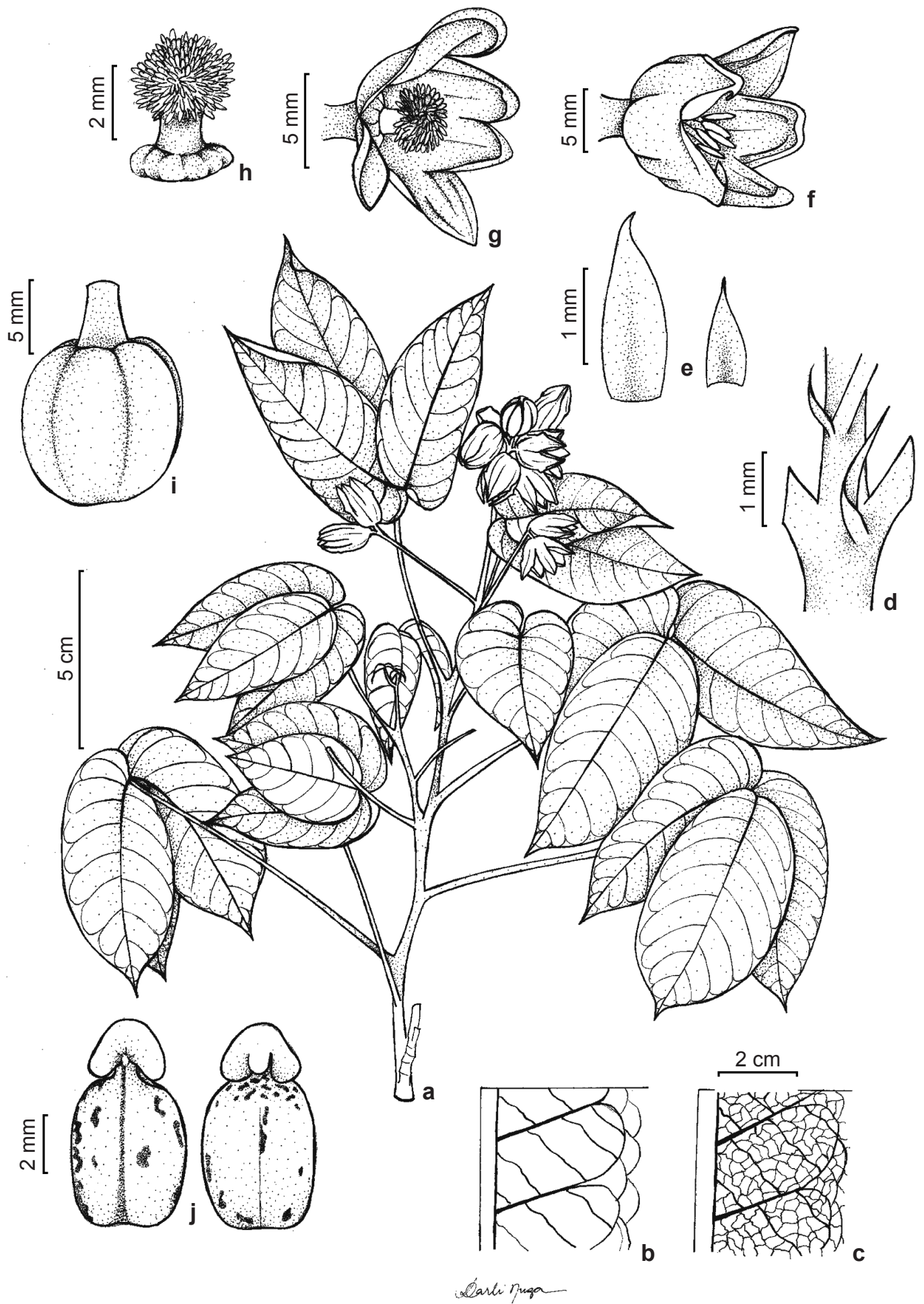

Figura 9-a-j. Manihot porphyrantha - a. hábito; b. detalhe nervação foliar, face adaxial; c. detalhe nervação foliar, face abaxial; d. estípulas; e. bráctea e bractéola (da esquerda para direita); f. flor estaminada; g. flor pistilada; h. gineceu; i. cápsula; j. sementes (a-h. Mendoza et al. 4368; i,j. Mendoza et al. 5075).

Figure 9 - a-j. Manihot porphyrantha - a. habit; b. detail of leaf venation, adaxial surface; c. detail of leaf venation, abaxial surface; d. stipules; e. bract and bracteole (from left to right); f. staminate flower; g. pistillate flower; h. gynoecium; i. capsule; j. seed (a-h. Mendoza et al. 4368; i,j. Mendoza et al. 5075). 
na região distal dos pedúnculos, 3-6(-9) $\mathrm{cm}$ compr., formada por um racemo central longo e 1-2 racemos laterais curtos, todos saindo do mesmo ponto; brácteas caducas, linear-lanceoladas, 2-2,5 $\times 0,8-1 \mathrm{~mm}$, margem inteira, ápice acuminado, glabras; bractéolas caducas, reduzidas. Flores curto- pediceladas, glabras na face externa, pubescentes na face interna, roxo-escuras a atropurpúreas, botões mais escuros; pedicelos das flores estaminadas $0,5-1 \mathrm{~mm}$ compr., das flores pistiladas $2-3 \mathrm{~mm}$ compr.; flores estaminadas globoso-campanuladas, $13-16 \times 10-13 \mathrm{~mm}$, tubo floral $8-9 \mathrm{~mm}$ compr.,

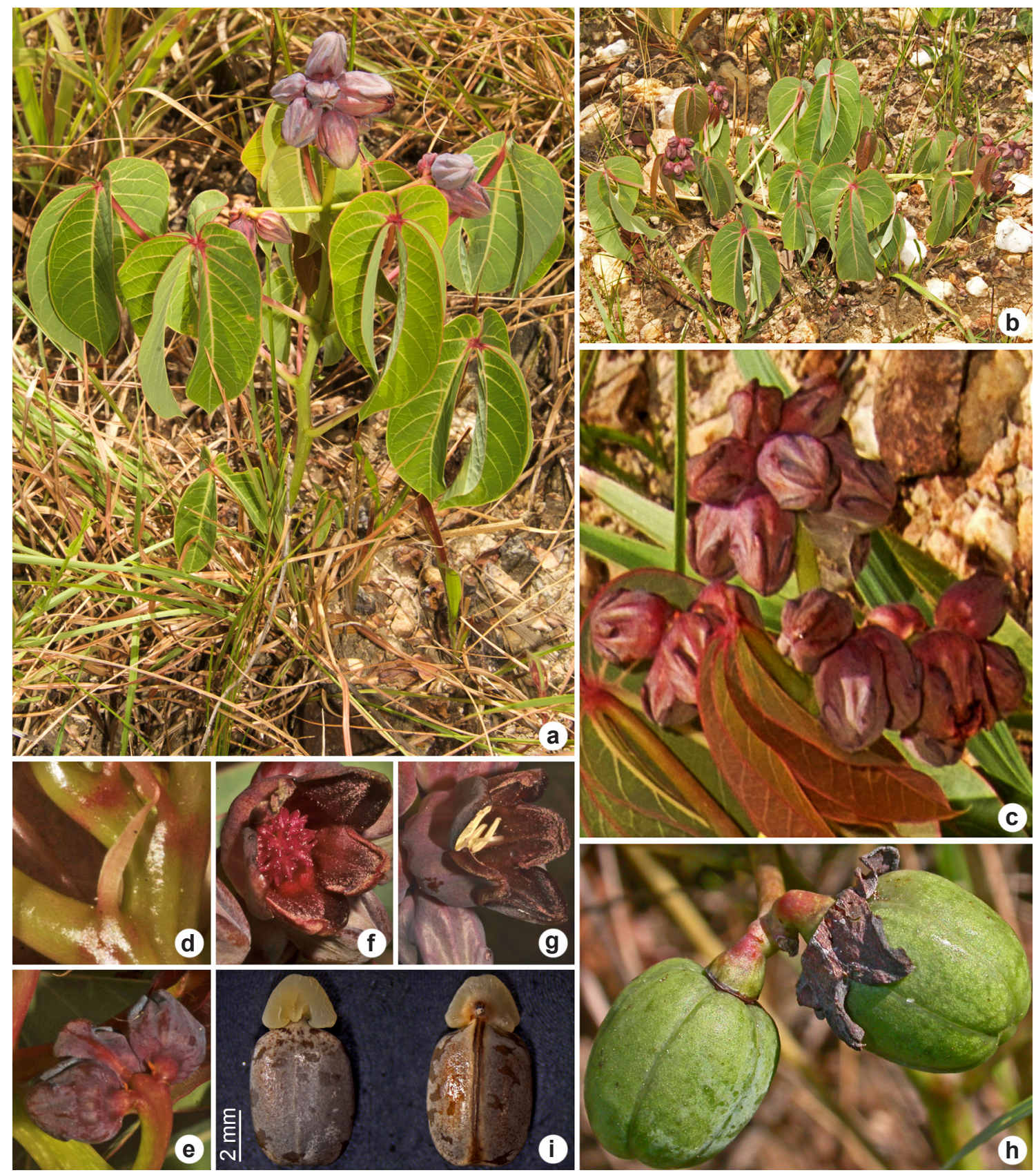

Figura 10 -a-i. Manihot porphyrantha - a,b. hábito; c. inflorescência; d. estípula; e. detalhe das brácteas e bractéolas; f. flor pistilada; g. flor estaminada; h. cápsula; i. sementes (a-g. Mendoza et al. 4368; h,i. Mendoza et al. 5075). Figure 10 - a-i. Manihot porphyrantha - a,b. habit; c. inflorescence; d. stipule; e. detail of bracts and bracteoles; f. pistillate flower; g. staminate flower; h. capsules; i. seeds (a-g. Mendoza et al. 4368; h,i. Mendoza et al. 5075). 
lobos das tépalas suavemente abertos, não reflexos, 5-7 mm compr., margem inflexa, papilosa na face interna; estames didínamos; flores pistiladas gamotépalas, globoso-campanuladas, levemente abertas, 7-8 × 6-7 mm, tubo floral 3-6 mm compr.; lobos das tépalas abertos (não reflexos), 3-4 mm compr., margem inflexa, papilosa na face interna; ovário elíptico, pistilos com estigmas amplos, atropurpúreos, ápice denso-papiloso. Cápsulas subglobosas, 11-12 × 10-11 mm, lisas, verdeglaucas; alas ausentes, depressões laterais finas. Sementes elípticas, 6-7 × 4-4,5 mm; carúncula fortemente proeminente, subreniforme, ápice rotundo.

Material adicional examinado: BRASIL. GOIÁS: Água Fria de Goiás, GO-237, ca. 11,3 km da GO-118, e entrando ca. 7,5 km sentido S, 14 56 ' 14 ''S, 4741'47'W, 1.042 m, 20.XI.2015, fl., M. Mendoza et al. 5075 (CEN, USZ). Mimoso de Goiás, ao longo de estrada vicinal à 40 km N de Padre Bernardo, 14'52'31''S, 48¹3'29'W, 1.164 m, 7.XI.2013, fl., M.F. Simon et al. 2019 (CEN, RB, UFG); na encosta do morro, 14'52'46"S, 48 14'0'"W, 1.150 m, 9.X.2013, fl., T.B. Cavalanti \& G. Pereira-Silva 3771 (CEN); norte de Padre Bernardo, ca. 38,7 km do trevo GO-230, e $700 \mathrm{~m}$ por trilha à esquerda, 1452'34'S, 48'13'43'W, 1.184 m, 5.VI.2015, fr., M. Mendoza et al. 5020 (CEN, K, NY, RB, USZ); ca $38,7 \mathrm{~km}$ do trevo GO-230, e $350 \mathrm{~m}$ por trilha à esquerda, 14 $52^{\prime} 36^{\prime \prime} \mathrm{S}$, 4813'32'W, 1.155 m, 4.XI.2014, fl., M. Mendoza et al. 4364 (CEN, LPB, MO, USZ); Serra Geral, 1452'29'S, 48'13'27'W, 900 m, 23.XI.2012, fl., G. Pereira-Silva 16457 (CEN, IAN).

Espécie endêmica de Goiás. Ocorre em zona montanhosa, em áreas preservadas de campo limpo, campo sujo até cerrado aberto, normalmente em encostas moderadas a fortemente pronunciadas ou áreas planas do topo das serras, em solo cascalhento e esbranquiçado, aos 1.050-1.200 m. Coletada com flores em outubro a dezembro e com frutos de novembro a junho.

O epíteto específico alude à cor atropurpúrea das flores e botões.

Manihot porphyrantha é caracterizada pelas inflorescências com flores concentradas no ápice dos pedúnculos; pelas flores robustas, globoso-campanuladas, de cor atropurpúrea, flores pistiladas gamotépalas com estigmas amplos de ápice denso-papiloso. Manihot porphyrantha é morfologicamente similar a $M$. congesta $M$. Mend. \& T.B. Cavalc., especialmente quando em fase vegetativa, pelo hábito reduzido, folhas 3-lobadas, estípulas caducas, frutos subglobosos, lisos e com fina depressão linear nas laterais. Manihot congesta se diferencia pelas flores de cor salmão, densamente dispostas ao longo dos pedúnculos, flores estaminadas tubular-campanuladas, as pistiladas dialitépalas (Tab. 1).

\section{Agradecimentos}

Os autores agradecem ao Departamento de Botânica da Universidade de Brasília e a Embrapa Recursos Genéticos e Biotecnologia por fazer possível o treinamento profissional do primeiro autor, o suporte institucional, e a acomodação logística. A John Wood, a revisão das diagnoses em Latim. Um agradecimento especial a todo o pessoal técnico e administrativo do Herbário CEN, particularmente a Bruno Machado Teles Walter. Ao projeto "Conservação de Recursos Genéticos Nativos e Parentes Silvestres da Flora do Cerrado" (Processo CNPq 457438/2012-6), que financiou o trabalho de campo, e ao projeto GEF/MMA/ EMBRAPA, que permitiu o estudo dos espécimes nos principais herbários brasileiros. $\mathrm{O}$ primeiro autor agradece a bolsa de PPG-Botânica, concedida pela CAPES (n ${ }^{\circ}$ 702643541-84).

\section{Referências}

Cavalcanti TB (2007) Novas espécies em Diplusodon Pohl (Lythraceae) do Planalto Central e Minas Gerais, Brasil. Acta Botanica Brasilica 21: 1-10.

Cordeiro I, Secco R, Silva MJ, Sodré RC \& Martins LML (2015) Manihot in Lista de Espécies da Flora do Brasil. Instituto de Pesquisas Jardim Botânico do Rio de Janeiro. Disponível em $<$ http://floradobrasil. jbrj.gov.br/jabot/floradobrasil/FB17591>. Acesso em 6 novembro 2015.

Martins ML \& Ledo CA (2015) Manihot cezarii (Euphorbiaceae), a new species from Central-Western Brazil. Novon 24: 179-181.

Mendoza FJM \& Cavalcanti TB (2015) Three new endemic species of Manihot (Euphorbiaceae) from Central Brazil. Q'euña 6: 7-22.

Mendoza FJM, Simon MF \& Cavalcanti TB (2015) Three new endemic species of Manihot (Euphorbiaceae) from the Chapada dos Veadeiros, Brazil. Arnaldoa 22: 297-312.

Mendoza FJM, Simon MF, Reis TS, Fidelis A \& Cavalcanti TB (2016) New endemic species of Manihot (Euphorbiaceae) from Serra do Tombador in Goiás, Central Brazil. Phytotaxa 273: 147-157.

Rogers DJ \& Appan SG (1973) Manihot and Manihotoides (Euphorbiaceae). A computer-assisted study. In: Organization for Flora Neotropica (ed.) Flora Neotropica Monograph 13. Hafner Press, New York. 272p.

Silva MJ, Sodré R \& Almeida LC (2013) A new endemic species of Manihot (Euphorbiaceae s. tr.) from the Chapada dos Veadeiros, Goiás, Brazil. Phytotaxa 131: 53-57. 
Silva MJ \& Sodré R (2014) A dwarf species of Manihot Mill. (Euphorbiaceae s.s.) from the highlands of Goiás, Brazil. Systematic Botany 39: 222-226.

Silva MJ (2014) Manihot veadeirensis (Euphorbiaceae s.s.): a new species from the Brazilian Cerrado, Brazil. Systematic Botany 39: 1161-1165.

Silva MJ (2015a) Manihot appanii (Euphorbiaceae s.s.): a new species from the Brazil, and a key to the species with unlobed or very shortly lobed leaves. Systematic Botany 40: 168-173.
Silva MJ (2015b) Two new wild cassava species (Manihot, Euphorbiaceae) from the Brazilian Cerrado. Phytotaxa 213: 131-139.

Silva MJ, Alonso A \& Sodré R (2016) Manihot pachycaulis sp. nov. (Euphorbiaceae) from the Brazilian Cerrado. Nordic Journal of Botany 34: 60-65.

Silva MJ (2016) Manihot gratiosa and M. lourdesii sp. nov. (Manihoteae, Euphorbiaceae) from the Brazilian Cerrado. Nordic Journal of Botany 34: 66-74. 